\title{
An Analysis of The Level of Polite Utterances in Sasak
Language: A Case Study in Central Lombok
}

\author{
Baiq Nurullayali ${ }^{1}$, Sartika ${ }^{2}$, Supriadin $^{3}$ \\ 1,2,3STKIP Paracendekia NW Sumbawa, Nusa Tenggara Barat, Indonesia \\ E-mail: nurullayali74@gmail.com, tikaika1692@gmail.com, supriadin1991@gmail.com
}

\begin{abstract}
Article Info
Abstract

Article History

Received: 2021-11-15

Revised: 2021-11-28

Published: 2021-12-12

This research aims to identify the way of polite language used by Sasak people in Central Lombok. In this research, qualitative descriptive method was employed in analyzing the data. There were three participants that consist of Sasak native speaker from two villages such as Beraim and Dakung village. The data were collected through three techniques that are, observation, interview and documentation. The Results of

Keywords:

Level; this research showed that firstly, Sasak language has three levels of polite utterances

Politeness; used by Sasak people such as most polite (Base Alus Utami), more polite (Base Alus Utterance;

Sasak Language. Madya), and polite (Base Sasak Biase). When kingdom was exist, Base Alus Utami only used by Perwangse, who was the king or people with high class level in Lombok Island and marked by Raden/Datu, and Dende at the first name. But, when they interacted with the lower class, they used biase language while the lower class of people must use Base Utami then, Base Alus Madya only used by people with the second level in society Baiq and Lalu at the first name, and Base Sasak Biase used by people with the lower class, called Jajar Karang. Secondly, the next generation in Sasak today do not really cosidere the rules when they using the polite language as people used in the past. It can be seen when they are communicating each other. They cannot able to speak with Base Alus Utami even speak with the older people. Only some of old people are still maintenance this language and teach their children but it is so rarely.
\end{abstract}

\begin{tabular}{l}
\hline Artikel Info \\
\hline Sejarah Artikel \\
Diterima: 2021-11-15 \\
Direvisi: 2021-11-28 \\
Dipublikasi: $2021-12-12$
\end{tabular}

Abstrak

Penelitian ini bertujuan mengidentifikasi cara tingkatan bahasa sopan digunakan oleh orang Sasak di Lombok Tengah. Dalam penelitian ini, metode kualitatif deskriptif digunakan untuk menganalisis data. Ada tiga partisipan yang terdiri dari penutur asli Bahasa Sasak dari dua desa, yakni Desa Beraim dan Dakung. Data-data tersebut diambil menggunakan tiga teknik yaitu kegiatan pengamatan, mewawancara, dan

Kata kunci:

Tingkatan;

Kesopanan;

Ucapan;

Bahasa Sasak. dokumentasi. Kegiatan proses wawancara telah direkam menggunakan telepon genggam. Hasil dari penelitian tersebut menunjukkan bahwa pertama, tingkatan ucapan-ucapan bahasa tersebut digunakan berdasarkan beberapa situasi, misalnya bahasa yang paling sopan (Base Alus Utami) digunakan pada suasana tertentu seperti kegiatan proses pernikahan. Kemudian, bahasa yang lebih sopan (Base Alus Madya) biasanya digunakan oleh orang-orang yang lebih muda kepada orang-orang yang lebih tua, dan Base Sasak Biase digunakan oleh orang-orang yang lebih tua ke orang-orang yang lebih muda dan orang-orang dengan umur yang sama. Akan tetapi, hasil penelitian ini juga membuktikan bahwa, saat ini, setiap orang dapat menggunakan level bahasa tampa memandang tingkat status social. Kedua, remaja saat ini seringkali tidak mempertimbangkan penggunaan bahasa sesui fungsinya. Bahkan mereka tidak mampu menggunakan bahasa sopan layaknya orang-orang terdahulu. Bahkan ketika mereka berbicara dengan orang yang lebih tua, mereka kurang mampu menerapkan bahasa Alus Utami. Ditemukan hanya sebagian kecil dari yang masih menggunakan bahasa sopan tersebut dan yang mengajarkan kepada anak-anaknya.

\section{INTRODUCTION}

Language plays an important role in all aspects of life. With language, a person is able to express the purpose of communication so that information and messages are able to be conveyed to other people. Moreover, Suwarna (2002, p. 4) states that language is a main tool of communication in daily life with other persons. Communication is an important thing for human life, and human particularly communicate with other persons using language, Therefore, when people use language, they have to use language appropriately. The use of language in everyday life should be in accordance with the circumstances and places where speaker uses the language, because the use of language does not fit into place will lead to a misunderstanding in communicating. In addition, there are many 
aspects in the language that must be understood by the people in order to avoid misunderstanding. One of the aspects that people have to be considered is the polite language. According to Ngalim (2013, p. 78), politeness is a form of agreed behavior in the relationship between personal feelings of each other match and give something that has a sense of mutual respect. Polite is the way in which the speaker appreciates and maintains the situation of the hearer in the interaction, but it is not a simple.

Sasak people are a group of people who uphold politeness, both politeness in behavior and also politeness in language. Sasak ethnic group who are live in Lombok Island, generally familiar with the use of Base Alus as the special term of polite language (Rosyidi, et al. (2017, p. 181). Since the 14th century, the Sasak people have been divided into four groups social castes, including perwangse (first caste, namely the nobility class), Menak (second caste), Jajar Karang (third caste, commoner or layman) and Sepangan (caste lowest or slave of an inferior class), the society of Sasak people who has a nobility title, usually identified by mention of the name as Lalu and Raden for men, and Baiq and Dende for women. The classification is based on the social stratification of the Sasak people as Menak (nobility class) or nonmenak (lower class). One way to differentiate attitude the relationship between the three groups is the use expressions using Sasak language, either base alus (polite language) or base jamaq (impolite language) which is regulated in the indhit base (speech level) of the Sasak language (Syahdan 2000, p. 99-109).

According to Zainul (2018), in Sasak there are three levels of language used by the society such as; firstly is Biase (ordinary language), where it used by old people to young people or people who has the same age but this language is not too polite. Secondly is Madya (more polite language), where it uses when young people interact with older people, the last is Utami (the most polite language), it usually used in special moments like in wedding process, where male's family come to female's family before nyongkolan, it is called Sorong Serah Aji Krame.

Ironically, the existence of using polite language of Sasak today is felt to be fading away. Today, most people especially younger generation unable to use this language in their life. Even they do not know how to use it correctly when they communicate one another. Moreover, Base Halus (polite language) does not specially teach to the children or students in the school since being applying the curriculum 2013 (K13). Therefore, the students as the next generation cannot use the most polite language as used by older people now days.

Based on the problems above, this research intends to investigate the way of Sasak people use the polite language in different level in Central Lombok especially in two villages such as Dakung and Beraim as the place of the research. The people who live in these villages have varieties of social stratification, economic, and education level.

Then, to support this research, there are three of relevant studies; 1) first was Zaenul (2018) "Bahasa Halus Kepada Anak Sebagai Bentuk Polieitnes Dalam Tingkat Tutur Bahasa Sasak". The results of this study indicated that there was an application of polite Sasak language to children as a form of respect, this result also as the first language acquisition of children and aims to build children's character from in the early age. The similarity between his research and this research was similarity in discuss and classify the speech level in Sasak language. While the differentiation with this research, were he just classified the speech level in general and focus on the application of polite language used by children as a form of respect to adult, while this research not only classify into some level but also explain them in more detail with the example. 2) Indah Yulianti et al. (2018) "Penerapan Bahasa Jawa Krama untuk Membentuk Karakter Sopan Santun di Sekolah Dasar." The similarity with this research is same in discussing about the classification of polite utterances. While the differentiation with this research is she just classify the level of polite language in Java generally and focuses on how the most polite of Java language can be applied in the school as one of subject learning for the students. Whilst in this research discusses about the speech level of politeness in Sasak language deeply, what the dominant levels are used by Sasak in Beraim and Dakung village. 3) Wilian \& Husaini (2018, p. 163) "Pergeseran Pemakaian Tingkat Tutur (Base Alus) Bahasa Sasak Di Lombok". The similarity with this research was to discuss about polite language in Sasak but the differentiation was they discussed or study about polite language of sasak in Lombok Island while this research just focused on two villages in Central Lombok such as Beraim and Dakung villages. 


\section{METHOD}

This research investigated the ways polite language used by Sasak people in daily interaction by looking at different situations. Based on the research objective, this research used qualitative descriptive as method of this study. Moleong (2007, p. 6) states that qualitative research is a research that analyzes the phenolmenon of what has happened and been experienced by the subjects descriptively in a natural context by applying scientific methodology.

A. Object and Setting of the Research

This research was conducted in Central Lombok exactly in two villages namely Dakung and Beraim Villages. These villages are located in Central Praya sub-district, Central Lombok regency. The residents who live in these villages consist of Sasak ethnic group with the varieties of social stratifycation, economic, and education level. The participants of this research were the native speaker of Sasak especially who live or inhibit in area of Dakung and Beraim Villages. They consisted of twenty people who are familiar with the three of polite languages in Sasak. This research was conducted in less than one year since November 2020 until June 2021.

B. Data Collection Techniques

There were three of techniques to collect the data in this research: first was observation, where in this study, the observation aimed to collect the data of linguistic situation in terms of how the native speakers of Sasak constructed some levels of speech in term of polite language when they communicated or interacted to one another in different situations. Second was interview technique, in this research, the data took interview technique exactly structured interview. The purpose of this technique is to know what is the level of polite utterances, that used by Sasak people in Central Lombok, then to identify the ways people used it, and to identify the dominant level of polite utterances used by Sasak people there. The last technique was documentation, according to Ibrahim in Sugiyono (2015, p.95), the documentation consist of writing, drawing or works form of someone, diary note, life histories, biography, letter and regulation.

In collecting data, the researcher used documentation technique. It refers to articles, and journals that related to the speech level in Sasak. The function of documentation in this reserarch, the researcher collected the data about the terms of polite utterances used by society that was started from past period until nowadays.

C. Instruments

In this section, the researcher used interview sheet and audio recorder. In addition to obtain the data about the ways Sasak people used the polite language, it used structure interview where participants answered in situation form and the participants answered based on the situation that asked before. While about audio recorder, the researcher used smartphone during interviewed.

D. Data Analysis

According Sugiyono (2014, p. 335) states that data analysis is the process of searching and compile systematically data obtained from interviews, field notes and documenttation by organizing data into categories, describing into units, synthesizing, arranging into patterns, choosing Which is important and that will be learned and make conclusions so easily understood by yourself and others. The data taken from observation, interview, and documentation then analyzed using some steps namely identifying, classifying, descrybing, explaining and concluding.

\section{HASIL DAN PEMBAHASAN}

Based on the result of collecting data technique, there were three levels of polite language varieties in Sasak such as Base Alus Utami (most polite language variety) Base Alus Madya (more polite language variety), and Base Biase (polite language variety). In this section the researcher presents in what situations that Sasak people use the levels language variety and how they use it.

1. Base Alus Utami (Most Polite Sasak Language Variety)

Base Sasak Alus Utami is the Sasak language variety with the highest level of politeness compared to the other Sasak language variety such as Biase (polite language variety) and Madya (more polite language variety). Based on the result of observation and interview, Sasak people tend to use this level of language in certain situations, for example at weddings, when announcing or inviting people to come to the mushalla or mosque, when talking to people with high social status such as head of villagers, teachers, or preachers. Because in Lombok they are highly valued and respected. Therefore, the citizens must be very polite 
when they are talking to them. Besides that, People nowadays use Base Utami (most polite language variety) at any situations as presented below:

a) In the Traditional Events

Based on observation and interview, it was found that the Sasak people usually use the most polite level of language in any traditional events because it is considered sacred and this language is a symbol of mutual respect for each other. One example of a traditional ceremony that is often carried out by the Sasak people is during a wedding (Sorong Serah Aji Krame) as one of the stages of the wedding traditional ceremony in Sasak where there are representatives from each side of the man and woman and they have a dialogue using the most polite language (Base Alus) as stated in the following text:

"Singgih sewauh dewek titiang puniki hangangsawung salam seugami sne wawuh tinujon ring wong Muslimin lan wong Muslimat. Sane malingih, malungguh ring penantaran jembar puniki. Purun malih dewek titiang puniki hangangsung salam panembrame ring sanehan datu, raden, menak, buling, perwangse, triwangse-wangsa same pare kiyaim lebe, penghulu pendite, hatib, bilal, merebot same. Dane haji pare haji, pare santri, santri kabeh, permancemance negare, malinggih malungguh, ring penayuhan agung puniki. Sawireh onteng pribadi titiang puniki, jage need nurgehe make miwah kang nyaranging titiang puniki ring kiwe, ring tengen, muah ring untat titiang puniki, senamian jage titiang puniki ngelungsur penurgahe, moga mogi ketampi mekadi atur dewek titiang puniki sane wauh....dawek."

"Well, first of all, I personally should have to say greetings to all Muslims and Muslimats or everyone who already present at this great event. Furthermore, I extend my regards to high officials of gentility, to community leaders, village officials, families, all levels of society, priest students, hajj and those present in this place. I am personally and those who accompany me are facing all of you, both those sitting on the left, right and behind. I submit a permit application'

(Source: Murcahyanto \& Jaelani, 2015) b) When Inviting the Society

Based on the existing phenomena, the Sasak people also use most polite language (bahasa halus utami) when inviting someone or the community to come to the certain events, for example to come to the mosque/ mushalla, attend traditional events and other social activities as presented in two examples below:

"...pelungguh sami senamian saq tiang hormati, melalui corong niki tiang aturang undangan oleq bije jarin isiq Tuan guru H.Syawal sampun bejangkep muq yaqn begawe jari te bareng-bareng sami jamaah te lumbar jok Gedengne lemak aru inggas Zohor. Matur tampiasih".

(“...the honorable Ladies and gentlemen, through this speaker I deliver you that Tuan Guru H. Syawal's son have married and he will conduct wedding party, thus, please we go together to his house tomorrow after Zuhur prayer. Thank you".)

The text above discusses about someone who gives information to all residents in that village to come to the wedding party and to tell of people that his son already got married. The second example of invitation:

"Silaq pelungguh sami jamaah saq tiang hormati, berhubung lemak aru tame pause jari silaq saq nyeke sante-sante mangkin niki tebareng-bareng persiq mesigit aden saq sere semanget lumbar teraweh tiang. Matur tampasih".

("The honorable ladies and gentlemen, tomorrow we will get fast, thus, please to people who are not busy at home to clean our mosque together so that make our spirit to Taraweh prayer more over. Thank you".)

The text above discusses about someone who asks the participation of the community to come together to clean the mosque because it is going to come Ramadhan month and will be doing tarawih prayer.

c) When A Person Talks with Higher Social Class

The most polite language is not only use when there is an traditional events or 
invitation, but also it is used when a person speaks to other people who have higher social class. For example when talk with priest, teacher, or people who are respected in that village as the example below:

“...silaq ngiring simpang juluq pak guru leq gedeng tiang, mangkin yaq aru Magrib tiang".

("Please take a rest in my house, this is almost Magrib").

In the past, Sasak Halus Utami is used to speak to the King (Datu) and to all his family who are often called as Raden community. Raden is the highest social class in Sasak ethnic group. It means this language is tend to be used by the upper class environment to the same ethnic group to respect one another. However, this language is also used by the society who come from lower and middle social class such as Menak and Jajar Karang when they speak with interlocutor who come from highest social class in this case to Raden ethnic group as illustrated in the example below.

Amaq Bokah: Niki lanjaran de kaji, Raden! This is your cigarette, Raden!

Raden Sale: Aoq, adek lek atas meje tie! Yes, put it on the table!

Amaq Bokah: Nggih Raden. Yes, Raden

Nowadays, utami language can be used by everyone without see on the status social because it is as the symbol of politeness during communication. In the fact, utami language, only use in certain situation such as in wedding process and in the other special moments. Because the lack of users, this it makes unfamiliar in society especially for young generation.

2. Base Alus Madya (More polite Sasak Language Variety)

At this level of language, Sasak people use it when younger person is talking to an older person. For example, a child speaks with his parents, his brother, his teacher, and so on. However, uniquely, older people generally do not have to use this polite language when he/she talks to the children or someone who have lower social class. In addition, this level of language actually only applies to the Sasak people who categorized as Menak. Menak ethnic groups usually have noble titles with the names namely Baiq and Lalu before his/her name. However, due to the Kingdom had not been applied, so anyone can use this level of language without looking at the level of social class as presented in the example below:

P: "Mamiq, wah de bekelor?"

(Father, have you breakfast?)

Q: “Aok baiq" ("yes I am")

Nowadays, the Sasak Halus madya is used by the Jajar Karang community in daily communication with the same community itself even though it is not using broadly. Usually it is used to someone who older, new comer or guest, to people who are respected or who are portrayed in the community (such as preast, heads of village, sub-district head). To invite guests to come to the traditional events (such as circumcision, marriage).

3. Base Sasak Biase (Polite Sasak Language Variety)

The last level of Sasak polite language is Bahasa Sasak Biasa. Generally, this level of language is used when speakers talk to their peers, smaller than them and also common people where their ancestors used to have the lowest social status or called as Jajar karang. This is indicated by the absence of nobility titles at the beginning of their names. The use of this language is mostly used by the Sasak people when compared to the previous language level. The examples of the use of this language are as follows:

"Inaq, yak lalo mancing jok bendungan bareh galeng-galeng kance Ivan, yaq beng ko lalo?"

("Mother, I will go to fishing with Ivan this afternoon, can I go?")

\section{CONCLUSSIONS AND SUGGESTIONS \\ A. Conclussions}

Based on the result of the analysis in the previous chapter, there are three conclusions that can be taken in this research. The first, Sasak language has three levels of polite utterances used by Sasak people such as most polite (Base Alus Utami), more polite (Base Alus Madya), and polite (Base Sasak Biase). When kingdom was exist, Base Alus Utami only used by Perwangse, who was the king or people with high class level in Lombok Island and marked by Raden/Datu, and Dende at the 
first name. But, when they or interacted with the lower class of people, they used biase language while the lower class of people must use Base Utami then, Base Alus Madya only used by people with the second level in society Baiq and Lalu at the first name, and Base Sasak Biase used by people with the lower class, called Jajar Karang, However, nowadays, everyone can use all of the level of sasak language because the function of these language not also for communicating but as the symbol of politeness. Ironically, young generation do not care about Sasak language deeply. It can be seen when they are communicating. They cannot able to speak with Base Alus Utami even though speak with the older people. Only some of old people are still maintenance this language and teach their children but it is so rarely.

Secondly, each of the level of polite utterance used in different situation and based on who is the speaker will speak. Base Alus Utami usually used in certain situation such as in wedding process, to invite people in the mushalla or mosque, when speaks with someone who has high social class. While Base Alus Madya used when young people communicate with older people then, Base Sasak biase used when older people speak with younger people, and close friend.

\section{B. Suggestions}

After doing the research, there are some suggestions to the next students who wants doing the research relates to linguistics polite. This thesis only focuses on the level of polite utterances used by Sasak people: a case study in Central Lombok, For the further research, the researcher suggests the next researcher to conduct the research of linguistics polite that is about Sasaknese in wide scope. The next researchers can use more data especially about history how Sasak language can be existed. The researcher also hopes that the next researchers focus not only on linguistics forms but also literature that contain in Sasak language

\section{REFERENCES}

Ibrahim (2015). Methodology Penelitian Kualitatif. Bandung : Alfabeta.

Moleong, Lexy J. (2007). Metodologi Penelitian Kualitatif. Bandung: PT. Remaja Rosdakarya.

Ngalim, Abdul. 2013. Sosiolinguistik: Suatu Kajian Fungsional dan Analisisnya cetakan ke-1. Solo: PBSID FKIP UMS.

Pringgawidagda, Suwarna. (2002). Strategi Penguasaan Berbahasa. Yogyakarta: Adicita Karya Nusa.

Rosyidi, M., Marmanto, S., Djatmika (2017) Memudarnya Base Alus dikalangan Genersasi Mudapenutur Bahasa Sasak di Desa Tembeng Putik Lomboktimur. SEMNASBAHTERA, P. 181-186

Syahdan. (2000). Code-switching in the speech of elite Sasaks. In Peter K. Austin (ed.) Working Papers in Sasak, Vol. 2, 99-109. Melbourne:University of Melbourne

Sugiyono, (2014). Metode penelitian pendidikan. Bandung: Alfabeta.Wilian, S. \& Husaini, B.N. (2018). Pergeseran Pemakaian Tingkat Tutur (Base Alus) Bahasa Sasak di Lombok. Linguistik Indonesia. Vol.36, No. 2 P. 161-185.

Yulianti, I., Isnani, A., Zakkiyyah, A. L., Hakim, J. (2018). Penerapan Bahasa Jawa Krama Untuk Membentuk Karakter Sopan Santun di Sekolah Dasar. Kampus UMK Gondangmanis, Bae Kudus. ISBN:978-602-1180-70-9

Zaenul (2018). Bahasa Halus Kepada Anak Sebagai Bentuk Polieitnes Dalam Tingkat Tutur Bahasa Sasak. Jurnal Edukasi Sumba (JES). 